\title{
Ultrastructural characteristics of the synovial membrane in idiopathic haemochromatosis
}

\author{
H. RALPH SCHUMACHER, Jr. \\ From the University of Pennsylvania School of Medicine, Arthritis Section, Department of Medicine, Hospital of \\ the University of Pennsylvania, and the Veterans Administration Hospital, Philadelphia, Pennsylvania
}

Iron deposition in the synovium in haemochromatosis has long been recognized and its occurrence was reviewed extensively by Sheldon (1935). This caused little interest, however, until 1964, when an apparently distinctive joint disease with degenerative type arthritis and chondrocalcinosis was reported in haemochromatosis (Schumacher, 1964). Synovial biopsies in patients with the arthropathy have shown iron predominantly deposited in the synovial lining cells (Delbarre and Bontoux, 1966; de Sèze, Hubault, Kahn, Welfling, Jaffres, Mitrovic, and Solnica, 1966; Kra, Hollingsworth, and Finch, 1965; Schumacher, 1964). This report describes the first ultrastructural study of the synovium in haemochromatosis and shows iron deposition to be most prominent in lining cells rich in rough endoplasmic reticulum. These presumably synthetic cells have been termed Type B in contrast to the macrophage-like Type A lining cells (Barland, Novikoff, and Hamerman, 1962). This pattern of iron deposition in haemochromatosis is contrasted with the greater localization of synovial iron in macrophages in a number of other states.

\section{Material and methods}

Synovial membrane from five patients with idiopathic haemochromatosis was studied by light and electron microscopy. Criteria for diagnosis of haemochromatosis were:

(1) Cirrhosis of the liver with histological proof of profuse hepatic iron deposition with large amounts in liver parenchymal cells;

(2) Markedly elevated serum iron at some time;

(3) One or more of the following: diabetes, increased skin pigmentation, or otherwise unexplained cardiopathy.

All patients had characteristic degenerative joint changes as seen in haemochromatosis (Dymock, Hamilton, Laws, and Williams, 1970; Schumacher, 1964). All biopsied joints were clinically diseased. Only Patient 2 had very advanced degenerative arthritis. Further characterization of the subjects studied is shown in the Table. No patients had major abnormalities of liver function.

Specimens of synovium were obtained by needle biopsy (Parker and Pearson, 1963) in two patients, at surgery for knee arthroplasty in one, and at open biopsy of a metacarpalphalangeal joint in two others. Synovium for comparison was examined from three patients with chronic

Table Clinical particulars of five patients with idiopathic haemochromatosis

\begin{tabular}{|c|c|c|c|c|c|c|c|c|}
\hline \multirow{2}{*}{$\begin{array}{l}\text { Case } \\
\text { no. }\end{array}$} & \multirow{2}{*}{$\begin{array}{l}\text { Age } \\
(\text { yrs })\end{array}$} & \multirow{2}{*}{ Sex } & \multirow{2}{*}{$\begin{array}{l}\text { Duration (yrs) } \\
\text { since first } \\
\text { 'probable' } \\
\text { manifestation of } \\
\text { haemochromatosis }\end{array}$} & \multirow{2}{*}{$\begin{array}{l}\text { Phlebotomies } \\
\text { before } \\
\text { biopsy }\end{array}$} & \multirow{2}{*}{$\begin{array}{l}\text { Serum iron and } \\
\text { total iron } \\
\text { binding capacity } \\
\text { at time of } \\
\text { biopsy } \\
\end{array}$} & \multicolumn{2}{|l|}{ Biopsy } & \multirow{2}{*}{$\begin{array}{l}\text { Other known } \\
\text { diseases }\end{array}$} \\
\hline & & & & & & Site & Method & \\
\hline 1 & $\begin{array}{l}58 \\
51\end{array}$ & $\begin{array}{l}\mathbf{M} \\
\mathbf{F}\end{array}$ & $\begin{array}{r}12 \\
3\end{array}$ & $\begin{array}{r}0 \\
100\end{array}$ & $\begin{array}{l}300 / 350 \\
174 / 475\end{array}$ & $\begin{array}{l}\text { Knee } \\
\text { Knee }\end{array}$ & $\begin{array}{l}\text { Needle } \\
\text { Surgery }\end{array}$ & $\begin{array}{l}0 \\
\text { Carcinoma of } \\
\text { breast }\end{array}$ \\
\hline $\begin{array}{l}3 \\
4 \\
5\end{array}$ & $\begin{array}{l}62 \\
58 \\
55\end{array}$ & $\begin{array}{l}\mathbf{M} \\
\mathbf{M} \\
\mathbf{M}\end{array}$ & $\begin{array}{r}22 \\
18 \\
2\end{array}$ & $\begin{array}{r}0 \\
150 \\
71\end{array}$ & $\begin{array}{r}228 / 294 \\
35 / 315 \\
47 / 324\end{array}$ & $\begin{array}{l}\text { MC-P } \\
\text { MC-P } \\
\text { Knee }\end{array}$ & $\begin{array}{l}\text { Surgery } \\
\text { Surgery } \\
\text { Needle }\end{array}$ & $\begin{array}{l}\text { Hypertension } \\
\text { Duodenal ulcer } \\
0\end{array}$ \\
\hline
\end{tabular}

Patients 1, 2, 4, and 5 had familial haemochromatosis.

Patient 5 was a heavy drinker.

Accepted for publication April 3, 1972.

This work was supported in part by Clinical Research Center Grant 5 MO1 RR 40, Division of Research Resources, National Institutes of Health. Please address requests for reprints to: Prof. H. R. Schumacher, M.D., 206 Maloney Clinic Building, Hospital of the University of Pennsylvania, 36th \& Spruce Streets, Philadelphia, Penna. 19104, U.S.A. 
rheumatoid arthritis, a 14-year-old boy with osteochondritis dissecans and recurrent haemarthroses over 3 months, and a woman with recurrent knee haemarthroses for many years secondary to Gaucher's disease.

Specimens of synovial membrane were prepared for both light and electron microscopy. Portions of tissue for the former were fixed in Bouin's solution and stained with haematoxylin and eosin or Prussian blue stains. For electron microscopy small specimens of synovium were placed immediately in Karnovsky's formaldehydeglutaraldehyde fixative (Karnovsky, 1965) diluted 1:1 with $0.1 \mathrm{M}$ cacodylate buffer at $\mathrm{pH} 7.4$ and processed as previously described (Schumacher, 1969).

\section{Results}

Light and/or electron microscopy of the synovial specimens demonstrated iron deposition in all patients with haemochromatosis, in one of the three with rheumatoid arthritis, and in the patients with haemarthroses. The contrasting patterns of iron distribution seen by light microscopy in haemochromatosis and in rheumatoid synovium are shown in Fig. 1.

In haemochromatosis by light microscopy there was marked villous proliferation with moderate increase in lining cells. Iron occurred predominantly in the lining cells. Patients 1 to 3 had massive iron

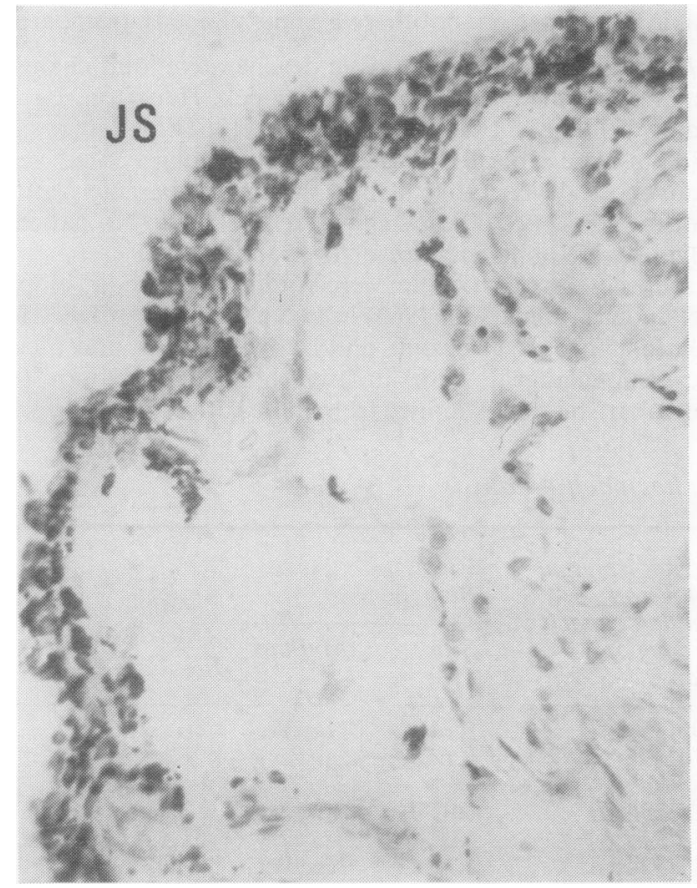

(A) Prussian blue stain. The iron is dark in this stain and is seen predominantly in synovial lining cells in idiopathic haemochromatosis. $\times 360$ deposition, while iron was present but sparse in Patients 4 and 5. Fibrous tissue was prominent in the deeper layers as was fixed tissue cell proliferation. Two patients had a few scattered lymphocytes. Synovial vessels were congested and in three instances there was perivascular fibrosis. There was very little iron in the deep connective tissue, only two patients having occasional haemosiderin in deep macrophages and giant cells. Two patients showed identifiable positively birefringent rodlike crystals typical of calcium pyrophosphate (McCarty, 1966). These were extracellular and not associated with any stainable iron. In one instance the crystals were embedded in an amorphous PAS positive matrix surrounded by giant cells. Bone and cartilage fragments were deposited in the synovium in Patient 2 , who had the most destructive arthritis.

Electron microscopic examination showed proliferation of Type A, B, and intermediate type lining cells (Barland and others, 1962). Dense iron deposits similar to those considered to be haemosiderin by Richter $(1957,1960)$ were seen in each type of lining cell, but the most common cell type and that with the most frequent iron was the Type B lining cell (Figs 2 to 4). These Type B cells were rich in rough endoplasmic reticulum which was occasionally dilated

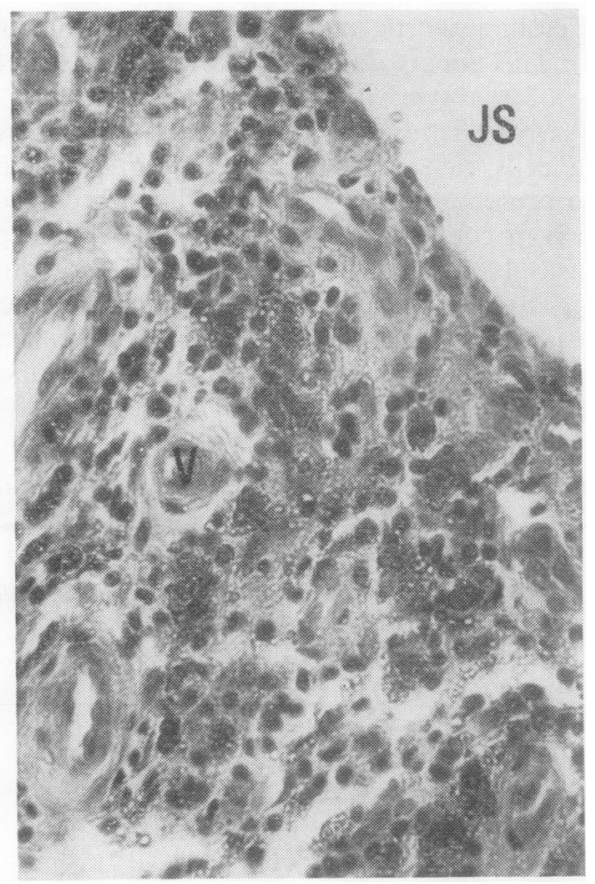

(B) Haematoxylin and eosin stain. The pale granules of iron after haematoxylin and eosin are seen in deep macrophages in the rheumatoid arthritis. The synovial lining here shows no iron. $\times 360$. JS $=$ Joint space. $\mathrm{V}=$ Small vessel.

FIG. 1 Light microscopy of synovium in haemochromatosis (left) and rheumatoid arthritis (right). 


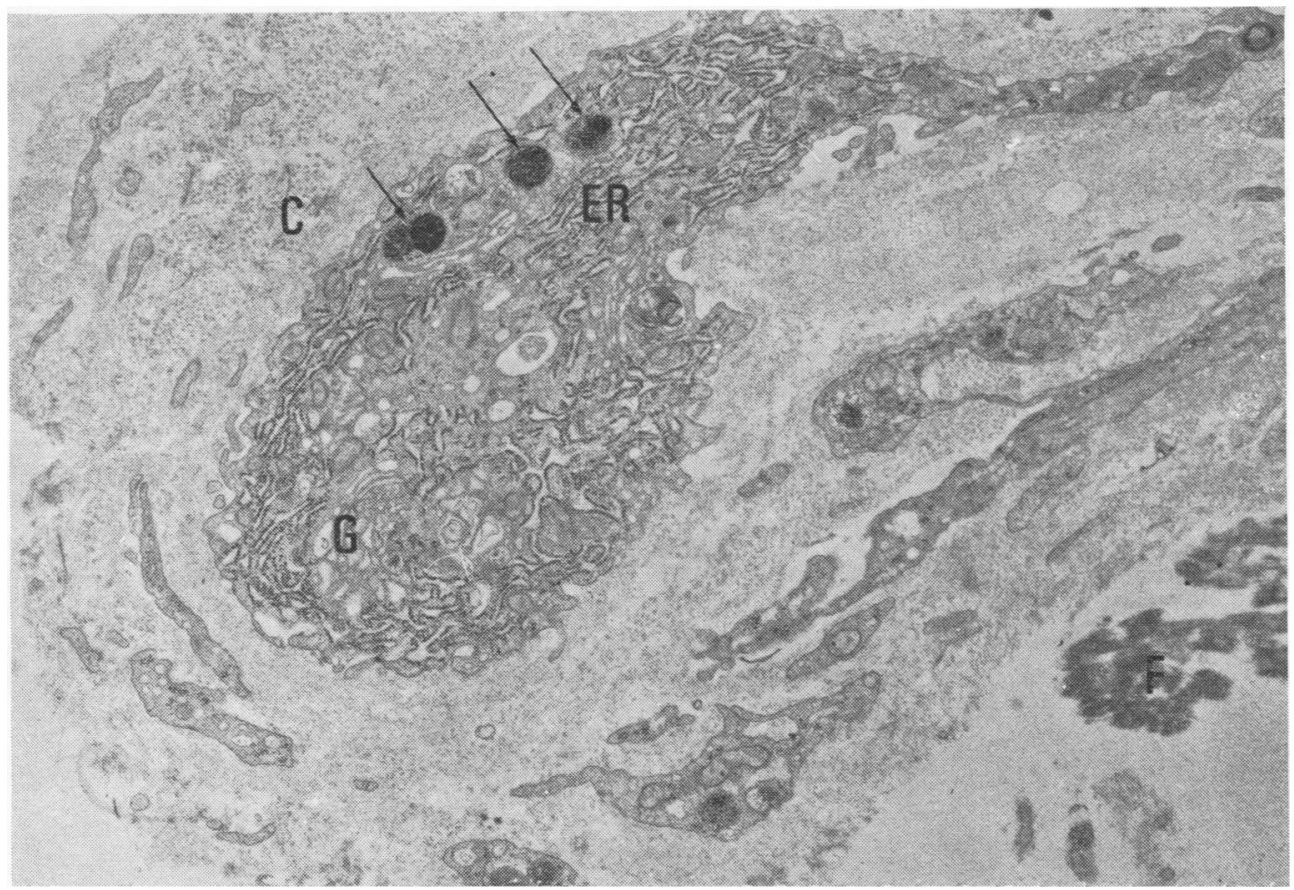

FIG. 2 Electron micrograph, showing Type B synovial lining cell with dense iron-containing inclusions (arrows). Rough endoplasmic reticulum is prominent $(E R) . G=$ Golgi apparatus. $C=$ Collagen fibres. $F=$ Fibrin-like material $. \times 11,000$

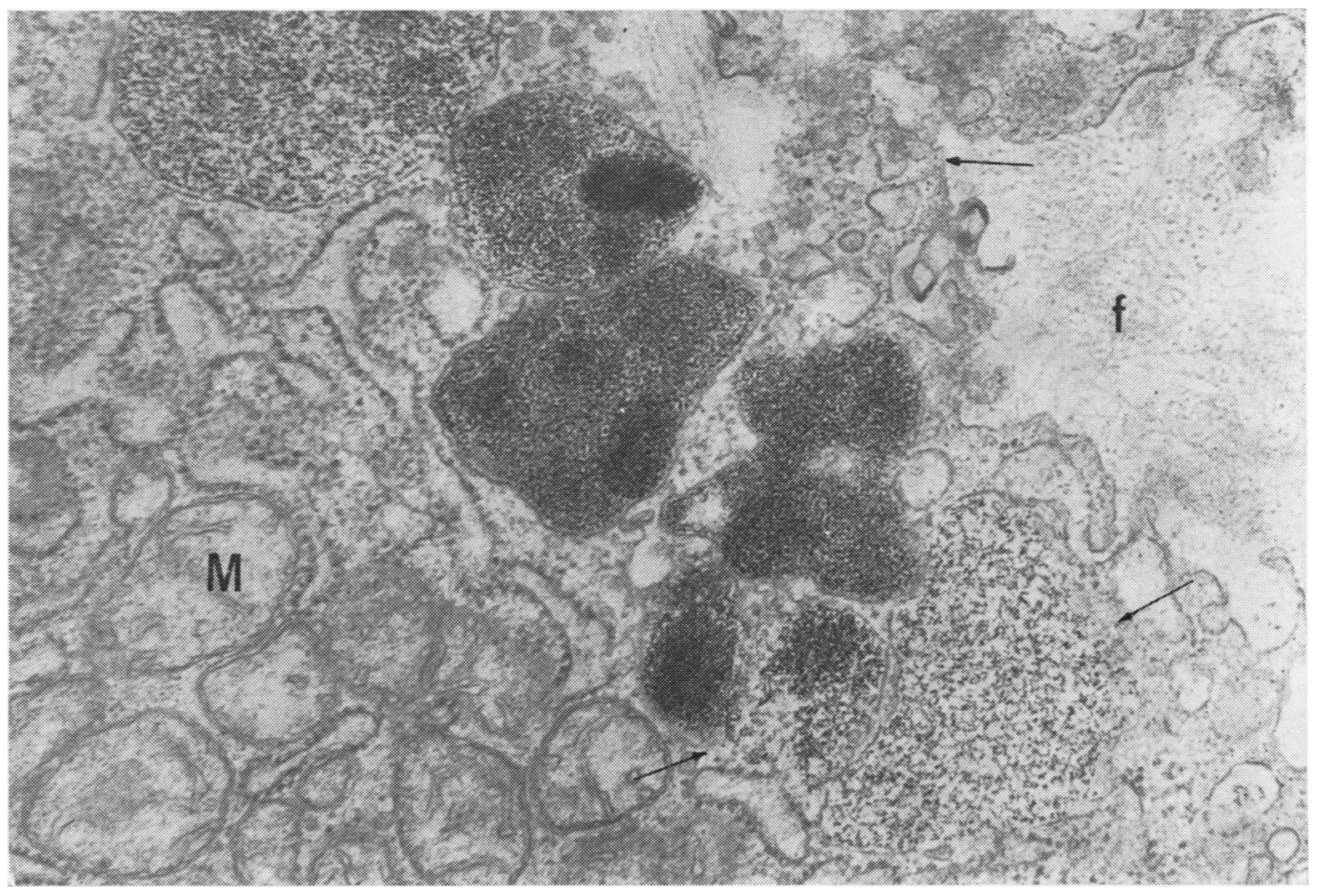

FIG. 3 Electron micrograph, showing iron deposits at higher magnification in Type B cell. Mitochondria (M) contain no iron. Most iron is seen in aggregates with surrounding membranes. Some aggregates are homogeneous while others have more dense foci within the aggregates. Some iron particles are not segregated by membranes (arrow). Fine extracellular fibrils $(f)$ without periodicit $\mathbf{N}$ ie adjacent to the cell. $\times 38,000$ 
and contained a faintly granular or fibrillar material. The electron dense iron was present in the cytoplasm between the cisternae. Some iron was scattered or occurred in aggregates without a bounding membrane, but most was in single membrane-bounded inclusions. All the iron in Patients 4 and 5 (who had been most completely iron depleted) was membrane bounded. Some aggregates had uniformly distributed particles while in others foci of more dense iron were also present (Fig. 3). Occasional vacuoles also contained some similar particles. The presumed ferritin particles showed no tetrad structure as described by Richter $(1957,1960)$. Hawkins, Mergner, Henkens, Kinney and Trump (1970) have recently demonstrated in high resolution studies ten subunits to the protein coat of ferritin but no consistent structure in the dense iron core. Iron was not seen in the cisternae of endoplasmic reticulum or in mitochondria. Almost all dense bodies in Type B cells contained iron. A well-developed Golgi apparatus showed no iron. Type A and intermediate cells when they did contain iron also had most of it in cytoplasmic aggregates. Most vesicles and vacuoles contained no iron. There was amorphous material or membranous arrays in some vacuoles and lipid was present in some dense bodies as is also seen in other joint diseases (Ghadially and Roy, 1967, Schumacher, 1968). Intercellular collagen was prominent and there were also fine filaments without identifiable periodicity adjacent to some Type B cells (Fig. 3). Fibrin-like material was present on the synovial surface (Fig. 2). Necrotic cells were identified and there was some iron in the interstitium near intact and necrotic iron-laden cells. No iron was seen in most areas of collagen.

Numerous vessels were notable mainly because of thick and often multilaminated basement membranes. Similar multilaminated basement membranes have also been seen in other diseased synovia (Schumacher, 1971) and are probably a non-specific

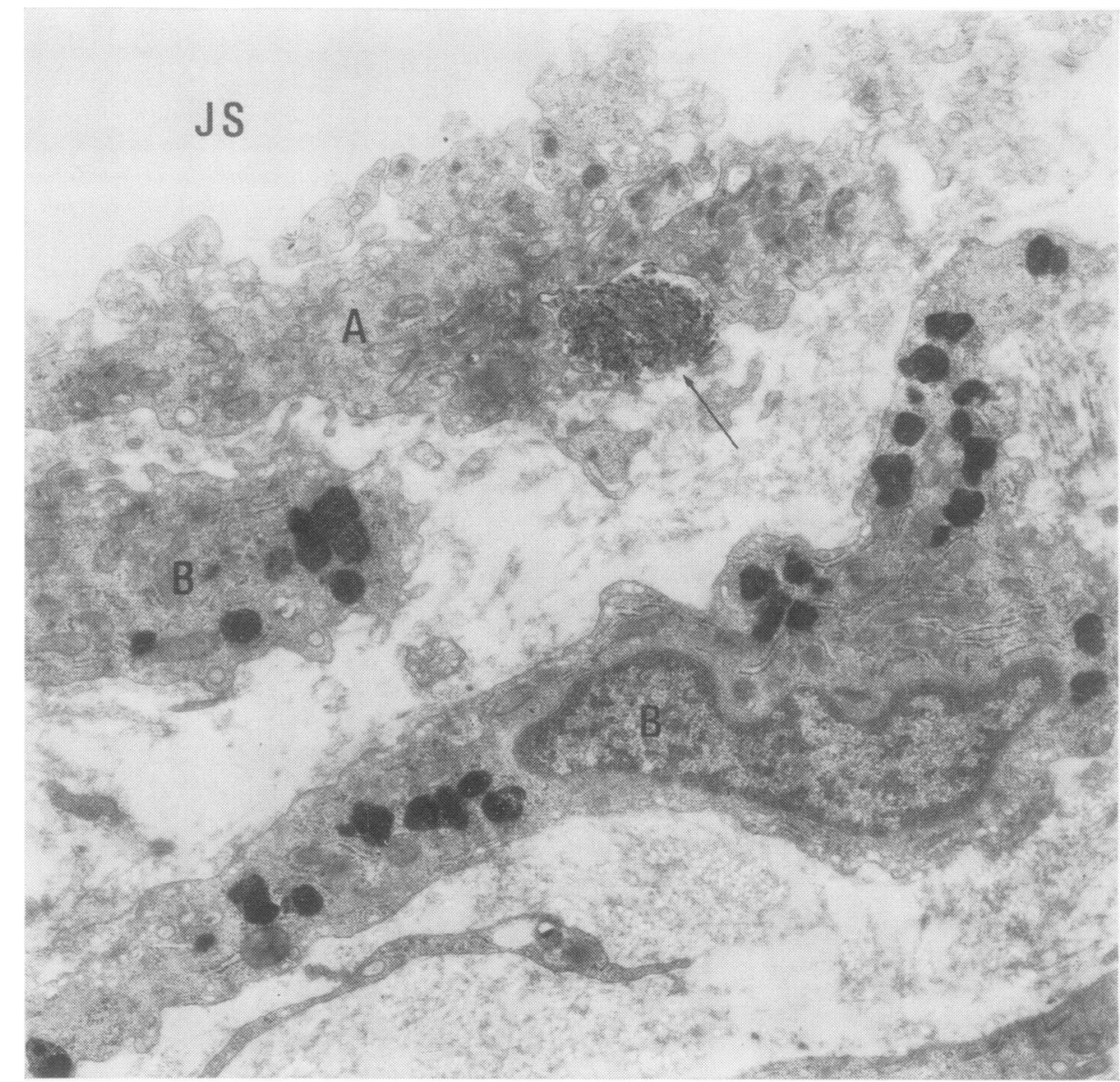

FIG. 4 Electron micrograph, showing synovial lining. Iron is seen in the deeper Type B lining cells $(B)$ with endoplasmic reticulum. There is little or no iron in the more superficial Type $A$ cells $(A)$. Beneath the Type $A$ cells is a small collection of rod-like electron dense fragments (arrow). JS = Joint space. $\times 11,000$ 
result of vascular injury. Iron was not seen in the vascular endothelium although there was a membrane-bound deposit in a pericyte. Occasional fibrocytes showed iron deposits. Several mast cells were seen and contained no iron particles.

Patient 2 had a collection of tiny electron dense rod-like fragments beneath one Type A lining cell (Fig. 4). These were consistent in appearance with hydroxyapatite.

In two patients there were crystals with an identical ultrastructural appearance to crystals of calcium pyrophosphate (Schumacher, 1968). These were deposited in synovial lining cells or in an amorphous matrix lying on the surface of the synovium (Fig. 5). No electron microscopic evidence of iron was seen near the crystals.

One patient with rheumatoid arthritis had iron by both light and electron microscopy in deep perivascular macrophages. The boy with recent haemarthrosis showed iron in synovial lining cells and large amounts in deep macrophages. Massive iron loading was seen in all synovial lining cell types but was greatest in the intermediate and Type A cells (Fig. 6, overleaf).

Except for the greater involvement of phagocytic cells, the iron deposits differed little from those of haemochromatosis. More iron was seen in vacuoles but some large vacuoles contained only small amounts of iron. In the synovium in the case of Gaucher's disease all the iron found was seen in macrophagelike cells except for one deposit in the venular endothelium and some extracellularly in areas containing cell debris. The iron was in unusually large clumps in vacuoles or apparently free in the cytoplasm. Occasional vacuoles had membranous whorls with smaller amounts of iron interspersed. Collagen was widespread but not as prominent immediately adjacent to the iron-containing cells as in haemochromatosis. No crystals were found in any synovia except those of haemochromatosis.

\section{Discussion}

COMPARISON OF SYNOVIAL IRON DEPOSITS WITH OTHER TISSUES IN HAEMOCHROMATOSIS The iron deposits in synovium in haemochromatosis are similar to those in other tissues in this disease (Bessis and Caroli, 1959; Kerr and Muir, 1960; Masuda, 1964; Matioli and Baker, 1963; Richter, 1957; Rüttner, Vogel, and Rondex, 1962; Scuro, Naccarato, Monti, and Sirigu, 1965; Williams, Scheuer, and Sherlock, 1962). Deposits are predominantly intracellular and either free in the cytoplasm or bounded by single membranes. Iron deposits in the liver appearing identical to those in the synovium, considered as haemosiderin by light

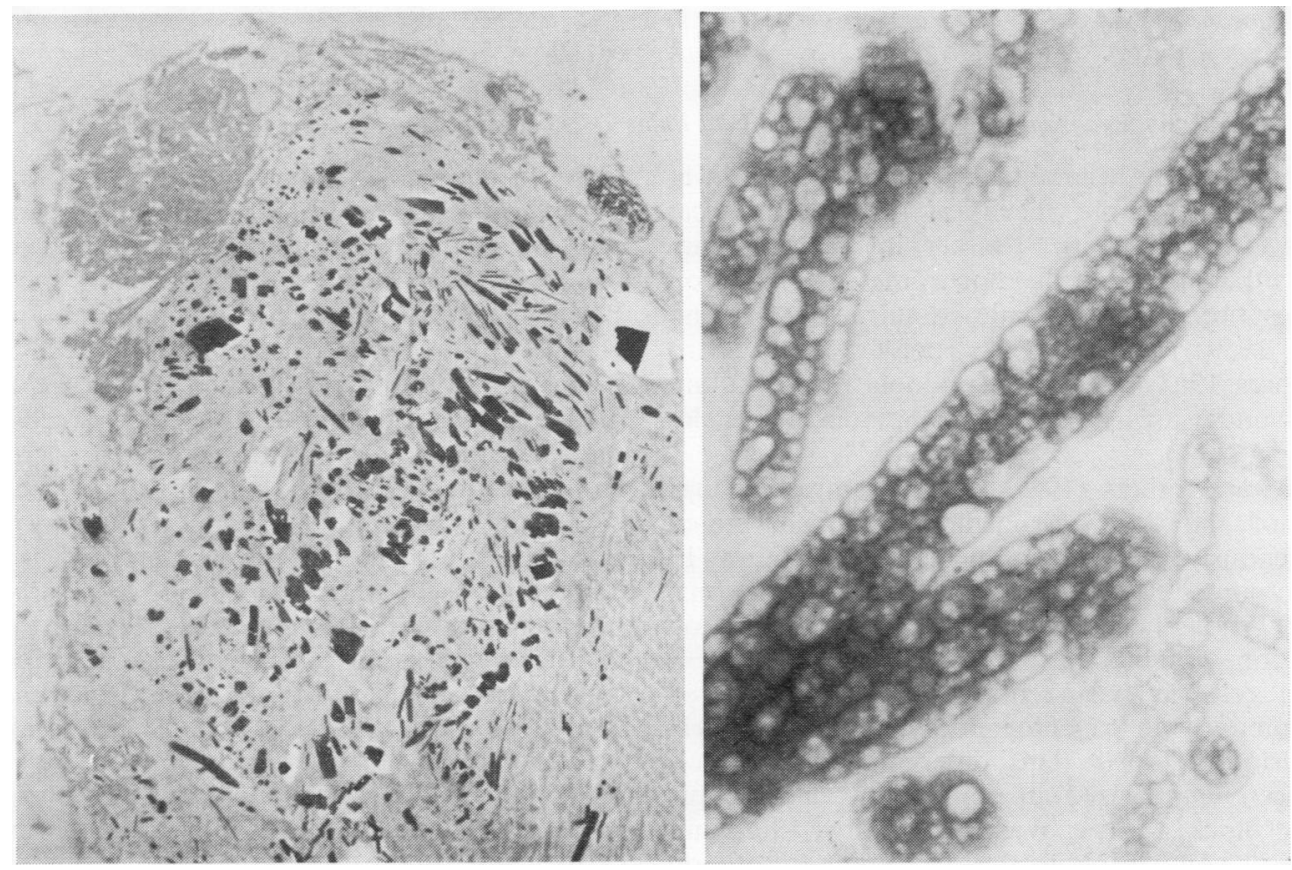

FIG. 5 (A) Crystals with ultrastructure characteristic of calcium pyrophosphate dihydrate lying on the surface of the synovium of Patient 3. Crystals are electron dense and show varying shapes. $\times$ 5,000

(B) A lace-like internal structure is seen in some of these crystals. $\times 80,000$ 


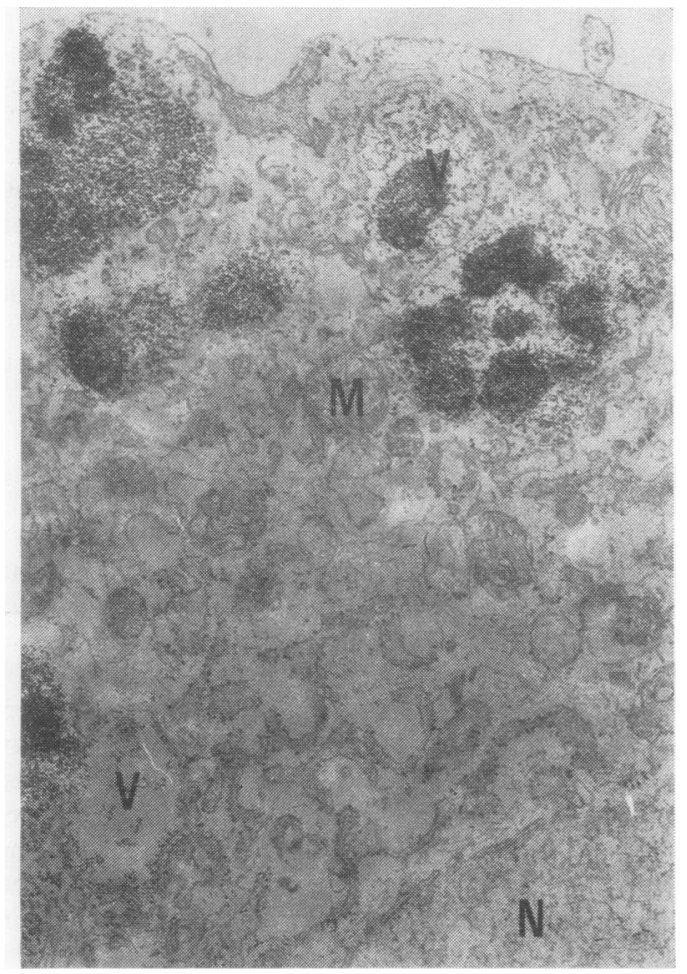

(A) Intermediate lining cell with varying amounts of iron in different vacuoles $(v) . M=$ Mitochondria. $N=$ Nucleus. $\times 22,000$

FIG. 6 Electron micrographs, showing iron in synovial lining cells in a patient with recent haemarthrosis.

microscopy, have been shown to contain ferritin in electron microscopic, chemical, and serological studies (Richter, 1960). Neither in the synovium nor in other tissues in haemochromatosis have iron particles been found in mitochondria (Bessis and Caroli, 1959; Masuda, 1964; Richter, 1960; Scuro and others, 1965), cisternae of endoplasmic reticulum (Bessis and Caroli, 1959), or in pinocytic vesicles (Masuda, 1964).

Scuro and others (1965), in their ultrastructural study of the liver in haemochromatosis, noted conspicuously dilated endoplasmic reticulum in hepatic parenchymal cells as we have seen in some Type B synovial cells. They also noted that the iron deposition was most prominent in hepatic parenchymal cells in haemochromatosis and occurred predominantly in reticuloendothelial cells in early transfusion siderosis. This differential pattern has also been emphasized in some light microscopic studies (Block, Moore, Wasi, and Haiby, 1965) and this seems comparable to the predominance of iron in synthetic Type B synovial lining cells rather than phagocytic cells in the synovium. Iron is also found in haemochromatosis in other cells probably synthe-

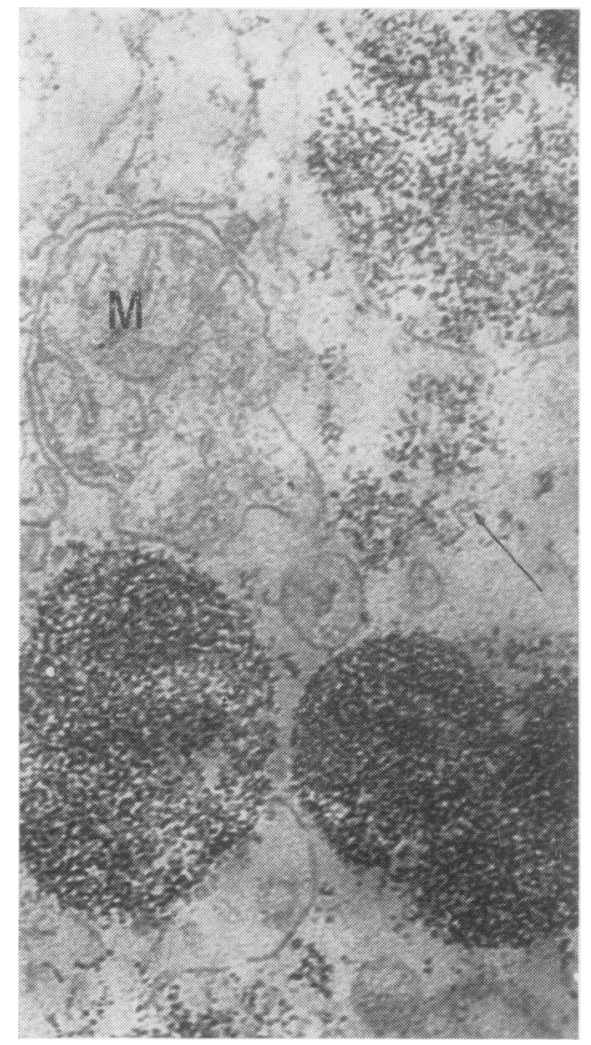

(B) Type A cell with iron aggregates and some iron free in the cytoplasm (arrow). $M=$ Mitochondrion. $\times 64,000$

sizing proteins for secretion. Zeitoun and Lambling (1966) found ferritin in gastric neck cells and chief cells. The iron in the latter report seemed to be in inclusions similar to the normal secretory inclusions. Bessis and Breton-Gorius (1962) and Goodman and Hall (1966) described ferritin in plasma cells.

One can speculate that there might be a basic metabolic defect in these synthesizing type cells, which may be important in the production of haemochromatosis. The smaller amounts of iron in phagocytic cells might arise either from phagocytosis after breakdown of Type B cells (interstitial iron was commonly seen) or a similar but lesser degree of production of ferritin in those cells. Ferritin synthesis at least in liver cells occurs on the free ribosomes (Hicks, Drysdale, and Munro, 1969; Redman, 1969), so that the earliest deposits may be free in the cytoplasm as seen in some synovia.

Prominent fibrous tissue as seen in the synovium is also seen in the livers with haemochromatosis (Scuro and others, 1965), but the prominence of small extracellular filaments seen in the synovium has not been commented upon. Such small fibres may be forms of immature collagen, as suggested 
by Dahmen (1968), but could also be protein polysaccharide or other material. Hayes and Rodnan (1971) have described similar narrow fibres in the dermis in scleroderma and have suggested that they represent active collagen fibrillogenesis.

There have been recent reports that the iron deposits seen by light microscopy occur in smaller particles in haemochromatosis than in some other types of iron overload (Nixon and Olson, 1968; Yam Finkel, Weintraub, and Crosby, 1968). In the synovium the larger iron aggregates have occurred in vacuoles in the diseases other than haemachromatosis, but no attempt has been made at a systemic comparison of aggregate size. Membranes and occasional layered arrays of membranes in siderosomes have been noted by Richter $(1957,1960)$ and Scuro and others (1965), who suggested that some may be lipofuscin. Occasional such membranous arrays and homogenous lipid deposits were also seen in synovium.

OTHER CAUSES OF IRON DEPOSITION IN THE SYNOVIUM

Iron has also been identified in synovium in other diseases including rheumatoid arthritis (Hirohata and Kobayashi, 1964; Muirden and Senator, 1968), osteoarthritis (Schumacher, 1971), haemarthrosis (Roy and Ghadially, 1966), pigmented villonodular synovitis (Wyllie, 1969), and haemophilia (Key, 1932). Almost invariably light microscopy in these situations has shown the iron to occur predominantly in deep macrophages in contrast to the more frequent localization to synovial lining cells in haemochromatosis. Electron microscopic studies in rheumatoid arthritis (Hirohata and Kobayashi, 1964; Muirden, 1966), pigmented villonodular synovitis (Wyllie, 1969), and in experimental hemarthrosis (Roy, 1968) or intra-articular iron dextran injection (Ball, Chapman, and Muirden, 1964), have all shown the iron predominantly in phagocytic cells, whether deep in the synovium or in the synovial lining. The Type B cells were always relatively spared in contrast to the findings in haemochromatosis. The proliferative reaction was also greater in the Type A cells in these studies. In the experimental animals, after intra-articular iron dextran or haemoglobin injections (Ball and others, 1964; Muirden, Fraser, and Clarris, 1967), haemosiderin deposits looked quite similar to those in haemochromatosis except for the localization to macrophage type cells. This agrees with the findings in the patients studied in this report with rheumatoid arthritis, haemarthrosis, and Gaucher's disease. In all these, in contrast to those with haemochromatosis, iron presumably arrived at the synovium from breakdown of erythrocytes in the joint space or synovial membrane. Iron has also been seen in the synovium in transfusion siderosis (Cappell, Hutchinson, and Jowett, 1957), but details of its light microscopic and ultrastructural distribution in the synovium have not been described. We have recently reviewed two synovia from patients with transfusion siderosis by light microscopy, and have been impressed with the predominance of iron in synovial lining cells (Schumacher, 1971). Brighton, Bigley, and Smolenski(1970), in systemic iron-loading studies in rabbits, found the synovial iron predominantly in the synovial lining cells. Most non-haemochromatic synovia did have small amounts of iron in clearly defined Type B cells, so that iron in these cells is certainly not specific for haemochromatosis (or other causes of systemic iron overloading). It is, however, much more common in those conditions than in the other joint diseases studied.

EFFECTS OF IRON ON THE SYNOVIUM

An injurious effect of iron in haemochromatosis, although often suggested, has not been established. Experimental iron administration alone has not produced haemochromatosis. In haemochromatosis some necrotic cells are loaded with iron but these morphological studies cannot establish the role of iron in the death of the cell. Iron may produce joint damage in a number of ways, by altering the products (collagen or other substances) synthesized by the Type B synovial cells, by reacting with extracellular protein polysaccharides as iron does in vitro in the Hale stain for protein polysaccharide, or by affecting lysosomes allowing abnormal release of lysosomal enzymes. Acid phosphatase studies of iron-containing inclusions after experimental iron administration have shown activity in some but not all iron-containing aggregates (Steiner, Phillips, and Miyai, 1964), suggesting that some iron at least after experimental administration occurs in lysosomes. Brighton and others (1970) have suggested that, since ferric iron (as in ferritin) has a high oxidation potential, it may increase the permeability of lysosomal membranes. Ferric iron may also oxidize the ascorbic acid which is required for hydroxylation of proline peptides and thus impair collagen formation.

Iron may make some direct contribution to calcinosis as suggested in 'sidero calcification' (Liber, 1965), and calciphylaxis (Selye, 1963), but the calcium in these lesions is hydroxyapatite not calcium pyrophosphate as in the chondrocalcinosis associated with haemochromatosis. The small clump of possible hydroxyapatite crystals found in one synovium was an isolated finding and may have been secondary to bone destruction from the more severe degenerative arthritis in this patient. These ultrastructural studies, as well as past light microscopic studies of cartilage (de Sèze and others; 1966), have shown no close spatial relationship between the iron and calcium pyrophosphate crystals. Thus, iron may contribute to calcium pyrophosphate deposition by indirect mechanisms such as effects on the Type B cells or the 
protein-polysaccharides of the ground substance in which the crystals deposit. Yaron, Yust, and Zurkowski (1969) have suggested that iron may inhibit a pyrophosphatase. McCarty, Pepe, Solomon, and Cobb (1970) have recently shown such inhibition in vitro by ferrous ions. Experimental iron overload has so far not been noted to produce chondrocalcinosis.

We have also noted iron in chondrocytes in preliminary studies of cartilage. Iron measurable in the synovial fluid has been reported to be considerably lower than the serum iron in a case studied by Muirden and Senator (1968), but Kra and others (1965) found a level similar to that in the blood. Certainly, despite the synovial changes shown in this study, it remains likely that alterations in the cartilage are major factors in producing degenerative arthropathy, changes in bone and synovial fluid also being of possible importance. The failure of experimental iron overload to produce tissue damage in most instances suggests that iron deposition may be only a secondary result of some yet unknown metabolic defect that produces the tissue damage. Almost all arthropathy in human iron overload has been seen in cases of idiopathic haemochromatosis, although clinical and $x$-ray changes in one apparent example of secondary haemosiderosis in hereditary spherocytosis have been reported (Dymock and others,
1970). Another possibility is that excess iron exposure must begin very early in life, as presumably occurs in haemochromatosis, but not in most secondary iron overload and experimental studies. Brighton and others (1970), after intramuscular iron and dextran loading in rabbits, noted articular cartilage degeneration only in young rabbits.

\section{Summary}

Iron is easily identified in the synovial lining cells of patients with untreated haemochromatosis. It is deposited predominantly in Type B synthetic cells in contrast to the macrophages and phagocytic Type A lining cells in which iron deposition is greatest in other conditions involving synovial iron overload. Iron deposits are in most respects similar to those noted in other tissues in haemochromatosis. Deposits of uniform particles and some denser clumps are free in the cytoplasm or bound by a single membrane. The mechanism of iron deposition in the joint and its role in the production of tissue damage remain undetermined.

The author acknowledges the valuable technical assistance of Miss Beatriz Senderowicz and Mrs. Margaret Hoffman. The micrographs of the pyrophosphate crystals were done by Miss Janet Parker.

\section{References}

Ball, J., Chapman, J. A., And Muirden, K. D. (1964) J. Cell Biol., 22, 351 (The uptake of iron in rabbit synovial tissue following intra-articular injection of iron dextran)

Barland, P., Novikoff, A. B., AND Hamerman, D. (1962) Ibid., 14, 207 (Electron microscopy of the human synovial membrane)

Bessis, M. C., AND Breton-Gorius, J. (1962) Blood, 19, 635 (Iron metabolism in the bone marrow as seen by electron microscopy: A critical review)

- AND CAROLI, J. (1959) Gastroenterology, 37, 538 (A comparative study of hemochromatosis by electron microscopy)

Block, M., Moore, G., Wasi, P., ANd Haiby, G. (1965) Amer. J. Path., 47, 89 (Histogenesis of the hepatic lesion in primary hemochromatosis: With consideration of the pseudo-iron deficient state produced by phlebotomies)

Brighton, C. T., Bigley, E. C., AND SMOlenski, B. I. (1970) Arthr. and Rheum., 13, 849 (Iron-induced arthritis in immature rabbits)

Cappell, D. G., Hutchinson, H. E., AND Jowett, M. (1957) J. Path. Bact., 74, 245 (Transfusional siderosis: The effects of excessive iron deposits on the tissues)

Dahmen, G. (1968) $Z$. Rheumaforsch., 27, 363 (Feingewebliche und Submikroskopische Untersuchungen bei Gutartigen Bindegewebsneubildungen am Beispiel des Fibroms. Fine structure and ultramicroscopic studies of benign connective tissue neoplasms using fibroma as an example)

Delbarre, F., ANd Bontoux, D. (1966) Bull. Soc. med. Hôp. Paris, 117, 881 (Signes et complications ostéoarticulaires de l'hémochromatose. Osteoarticular signs and complications of haemochromatosis)

Dymock, I. W., Hamilton, E. B. D., LaWs, J. W., AND Williams, R. (1970) Ann. rheum. Dis., 29, 469 (Arthropathy of haemochromatosis: Clinical and radiological analysis of 63 patients with iron overload)

Ghadially, F. N., AND RoY, S. (1967) Ibid., 26, 426 (Ultrastructure of synovial membrane in rheumatoid arthritis)

Goodman, J. R., AND Hall, S. G. (1966) Blood, 28, 83 (Plasma cells containing iron: An electron micrographic study)

Hawkins, H., Mergner, W. J., Henkens, R., Kinney, T. D., And Trump, B. F. (1960) 'Attempts at resolution of the subunit structure of ferritin and apoferritin by electron microscopy', in 'Proc. Electron Microscopy Society of America', p. 268. Claitors Publishing Division, Baton Rouge, Louisiana

Hayes, R. L., AND Rodnan, G. P. (1971) Amer. J. Path., 63, 433 (The ultrastructure of skin in progressive systemic sclerosis. I. Dermal collagen fibers) 
Hicks, S. J., Drysdale, J. W., AND Munro, H. N. (1969) Science, 164, 584 (Preferential synthesis of ferritin and by different populations of liver polysomes)

HiRohata, K., AND Kobayashi, I. (1964) Kobe J. med. Sci., 10, 195 (Fine structures of the synovial tissues in rheumatoid arthritis)

KarNovsky, M. J. (1965) J. Cell Biol., 27, 137A, Abstr. no. 2705 (A formaldehyde-glutaraldehyde fixative of high osmolality for use in electron microscopy).

KeRR, D. N. S., AND MUIR, A. R. (1960) J. Ultrastruct. Res., 3, 313 (A demonstration of the structure and disposition of ferritin in the human liver cell)

KeY, J. A. (1932) Ann. Surg., 95, 198 (Hemophilic arthritis)

Kra, S. J., HollingsworTh, J. W., AND FinCH, S. C. (1965) New Engl. J. Med., 272, 1268 (Arthritis with synovial iron deposition in a patient with hemochromatosis)

LIBER, A. F. (1965) J. Neuropath. exp. Neurol., 24, 675 (Chelatable iron in senile siderocalcification of the human brain)

MASUDA, M. (1964) T. Gastro-ent., 7b, 165 (An electron microscopic study of the liver and gastric mucosa of primary hemochromatosis)

MATIOLI, G. T., AND BAKER, R. F. (1963) J. Ultrastruct. Res., 8, 477 (Denaturation of ferritin and its relationship with hemosiderin)

McCARTY, D. J. (1966) 'Pseudogout: Articular chondrocalcinosis. Calcium pyrophosphate crystal deposition disease', in 'Arthritis and Allied Conditions', ed. J. L. Hollander, 7th ed., p. 947. Lea and Febiger, Philadelphia

- PePe, P. F., Solomon, S. D., AND CoBb, J. (1970) Arthr. and Rheum., 13, 336 (Inhibition of human erythrocyte pyrophosphatase activity by calcium, cupric and ferrous ions)

Muirden, K. D. (1966) Ann. rheum. Dis., 25, 387 (Ferritin in synovial cells in patients with rheumatoid arthritis)

, Fraser, J. R. E., AND Clarris, B. (1967) Ibid., 26, 251 (Ferritin formation by synovial cells exposed to haemoglobin in vitro)

- AND SENATOR, G. B. (1968) Ibid., 27, 38 (Iron in the synovial membrane in rheumatoid arthritis and other joint disease)

Nixon, R. K., AND Olson, J. P. (1968) Ann. intern. Med., 69, 1249 (Diagnostic value of marrow hemosiderin patterns)

Parker, R. H., ANd Pearson, C. M. (1963) Arthr. and Rheum. 6, 172 (A simplified synovial biopsy needle)

REDMAN, C. M. (1969) J. biol. Chem., 244, 4308 (Biosynthesis of serum proteins and ferritin by free and attached ribosomes of rat liver)

RichteR, G. W. (1957) J. exp. Med., 106, 203 (A study of hemosiderosis with the aid of electron microscopy)

- (1960) Ibid., 112, 551 (The nature of storage iron in idiopathic hemochromatosis and in hemosiderosis)

Roy, S., and Ghadially, F. N. (1966) Ann. rheum. Dis., 25, 402 (Pathology of experimental haemarthrosis)

RÜTTNER, J. R., VOGEL, A., AND RONDEX, R. (1962) Schweiz. med. Wschr., 92, 452 (Fine structure study of the iron uptake in the liver in hemochromatosis)

SChumacher, H. R. (1964) Arthr. and Rheum., 7, 41 (Hemochromatosis and arthritis) (1968) Ibid., 11, 426 (The synovitis of pseudogout: Electron microscopic observations)

- (1969) Ibid., 12, 387 (The microvasculature of the synovial membrane of the monkey: Ultrastructural studies) - (1971) Unpublished observations

Scuro, L. A., Naccarato, R., Monti, G., and Sirigu, F. (1965) Pánminerva Med., 7, 116 (Morphological liver changes in hemochromatosis: Optical and electron microscopy studies)

Selye, H. (1962) 'Calciphylaxis', p. 356. Chicago University Press

Sèze, S. de, Hubault, A., Kahn, M. F., Welfling, J., Jaffres, R., Mitrovic, D., and Solnica, J. (1966) Sem. Hôp. Paris, 42, 2472 (Les arthropathies des hemochromatoses. The arthropathies of hemochromatosis)

Sheldon, J. H., (1935) 'Haemochromatosis'. Oxford University Press, London

Steiner, J. W., Phillips, M. D., AND MiYai, K. (1964) 'Ultrastructural and Subcellular Pathology of the Liver', in 'International Review of Experimental Pathology', ed. W. Richter and M. A. Epstein, vol. 3, p. 134. Academic Press, New York

Williams, R., Scheuer, P. J., ANd Sherlock, S. (1962) Quart. J. Med., 31, 249 (The inheritance of idiopathic haemochromatosis. A clinical and liver biopsy study of sixteen families)

WyLlie, J. C. (1969) Arthr. and Rheum., 12, 205 (The stromal cell reaction of pigmented villonodular synovitis: An electron microscopic study)

Yam, L. T., Finkel, H. E., Weintraub, L. R., ANd Crosby, W. H. (1968) New Engl. J. Med., 279, 512 (Circulating iron containing macrophages in hemochromatosis)

YARON, M., YUST, I., AND ZURKOWSKI, P. (1969) Lancet, 2, 651 (Alkaline phosphatase in pseudogout)

Zertoun, P., and Lambling, A. (1966) Scand. J. Gastroent., 2, 222 (Ultrastructure of the gastric mucosa in human hemachromatosis) 